\title{
Spatial behavior of the thermo-luminous conditions of facility laying hens in naturally ventilated vertical system
}

\section{Comportamento espacial das condições termo-luminosas do aviário de poedeiras em sistema vertical naturalmente ventilado}

\author{
Letícia Cibele da Silva Ramos Freitas ${ }^{1 *}$, Ilda de Fátima Ferreira Tinôco ${ }^{1}$, Richard Stephen Gates², \\ Cecília de Fátima Souza ${ }^{1}$, Matteo barbari³ ${ }^{3}$ Carlos Gutemberg de Souza Teles Junior ${ }^{1}$
}

\author{
${ }^{1}$ Universidade Federal de Viçosa/UFV, Departamento de Engenharia, Viçosa, Minas Gerais, Brasil \\ 2University of Illinois at Urbana-Champaign, Champaign, Illinois, United States of America \\ ${ }^{3}$ Università degli Studi di Firenze, Dipartimento di Gestione dei Sistemi Agrari, Firenze, Italia \\ *Corresponding author: leticiacibele@yahoo.com.br \\ Received in August 21, 2018 and approved in October 9, 2018
}

\begin{abstract}
The facilities for laying hens should be designed to provide thermal comfort and satisfactory luminosity for the production of quality eggs. The objective of this study was to evaluate the spatial behavior of thermal conditions and light intensity of facilities for laying hens with vertical cages naturally conditioned during winter and summer. Air temperature, air relative humidity and light intensity data were collected in 75 points distributed evenly through the longitudinal direction of the installation in three tiers of cages (first, third and sixth). Each point represented a set of coordinates $(x, y, z)$, being the $x$-axis the lines ( $L 1, L 2, L 3, L 4, L 5)$, $y$-axis the sections $(S 1, S 2, S 3, S 4, S 5)$ and z-axis the tiers (N1, N2, N3). The spatial behavior of the thermal conditions of the facility was held during the coldest period of winter and the warmest period of summer. The experimental design was completely randomized in a factorial scheme. In the winter, the temperature showed homogeneous behavior among sections and variable among lines. In the summer, the spatial variability of temperature and humidity was more accentuated than in the winter, mainly among tiers. For both seasons, the center of the facility presented lower light intensity than the lateral. From the spatial behavior of the thermal conditions of the facility laying hens, it is possible to verify the magnitude and variability of temperature, relative humidity and light intensity, identify vulnerable and deficit thermal regions and contribute to decision-making related to thermal conditioning and luminosity of the facility.
\end{abstract}

Index terms: Characterization of the environment; thermal variability; light intensity.

\begin{abstract}
RESUMO
As instalações para galinhas poedeiras devem ser concebidas para proporcionarem conforto térmico e satisfatória luminosidade para uma produção de ovos de qualidade. O objetivo deste estudo foi avaliar o comportamento espacial das condições térmicas e intensidade luminosa de aviários verticais para galinhas poedeiras acondicionados naturalmente, durante o inverno e verão. Dados de temperatura do ar, umidade relativa do ar e intensidade luminosa foram coletados em 75 pontos distribuídos uniformemente no sentido longitudinal do aviário, em três andares de gaiolas, (primeiro, terceiro e sexto). Cada ponto representava um conjunto de coordenadas $(x, y, z)$ sendo no sentido do eixo $x$ as linhas $(L 1, L 2, L 3, L 4, L 5)$ eixo y as seções (S1, S2, S3, S4, S5) e eixo z os níveis (N1, N2, N3). O comportamento espacial das condições térmicas do aviário foi realizado no período mais frio do inverno e mais quente do verão. O delineamento experimental adotado foi inteiramente casualizado em esquema fatorial. No inverno, a temperatura apresentou comportamento homogêneo entre as seções e variável entre linhas. No verão, a variabilidade espacial da temperatura e umidade foi mais acentuada que no inverno, principalmente entre os níveis. Para ambas as estações o centro do aviário apresentou intensidade luminosa menor que as laterais. A partir do comportamento espacial das condições térmicas do aviário de poedeiras é possível verificar a magnitude e variabilidade da temperatura, umidade relativa e intensidade luminosa, identificar regiões vulneráveis e deficitárias termicamente e contribuir para a tomada de decisões relacionadas ao acondicionamento térmico e luminosidade da instalação.
\end{abstract}

Termos para indexação: Caracterização do ambiente; variabilidade térmica; intensidade luminosa.

\section{INTRODUCTION}

Thermal stress is a major concern for poultry farming, especially in hot regions, which may lead to low yields and high mortality rates (Balamurugan et al., 2017). The environmental condition of the facility is fundamental for the effective performance of the metabolic, endocrinological and physiological activities related to the process of egg production. The laying hens' facilities must be designed to maintain the ideal thermal condition for the production of the birds, avoiding the thermal stress.

At ambient temperatures below $15{ }^{\circ} \mathrm{C}$, laying hens have a low production performance and worse feed conversion. In the range of $15{ }^{\circ} \mathrm{C}$ to $26{ }^{\circ} \mathrm{C}$ there is an improvement in zootechnical performance, with the ideal 
ambient temperature being in the range from $24^{\circ} \mathrm{C}$ to $26^{\circ} \mathrm{C}$. From $27{ }^{\circ} \mathrm{C}$, the productive efficiency decreases and, when approaching $30{ }^{\circ} \mathrm{C}$, there is a marked reduction in feed consumption and egg quality. At $32{ }^{\circ} \mathrm{C}$, there is an impairment in the thermo-regulation of the laying hens (Ferreira, 2015).

The effect of air temperature on the performance of laying hens will be more harmful as the higher air relative humidity, so these parameters must be monitored and controlled in order to ensure egg productivity and quality (Albino et al., 2014). The knowledge of the spatial behavior of the thermal variables in the poultry facilities is important for the decision-making on the best way to conditioning the environment.

The Light intensity and photoperiod are important for the performance of laying hens and may affect egg production for the reproductive system stimulated via hypothalamic photoreceptors (Nunes et al., 2013). In open facilities, 10 lux of light intensity in the cage (hen's head) are required for egg production (Cotta, 2014; Jácome; Rossi; Borille, 2014). In naturally ventilated of the laying hens facilities with vertical cages, the light intensity may vary due to the arrangement of barrier cage batteries, reducing the incidence of external light into the aviary.

The objective of this research was to evaluate the spatial behavior of the thermal conditions and light intensity of the facility of the laying hens with vertical cages and naturally conditioned, during winter and summer.

\section{MATERIAL AND METHODS}

\section{Facilities characteristics}

The experiment was carried out in a facility for laying hens of high density, with vertical system of cages and natural ventilation, located in the southern region of the state of Minas Gerais, Brazil, geographical coordinates $22^{\circ} 17^{\prime} 45^{\prime \prime} \mathrm{S}$ and $44^{\circ} 56^{\prime} 05^{\prime \prime} \mathrm{W}$ and average altitude of $892 \mathrm{~m}$. The facility is made out of a metallic structure, non-insulated galvanized steel roof, dimensions of 134.0 x $12.5 \mathrm{~m}$ (length $\mathrm{x}$ width), $5.0 \mathrm{~m}$ high and with a covered open ridge of $1.2 \mathrm{~m}$ of width.

The facility houses four batteries of vertical cages, each with six tiers. Each cage has dimensions of $0.6 \times 0.5 \times$ $0.4 \mathrm{~m}$ (width $\mathrm{x}$ depth $\mathrm{x}$ height), housing ten hens per cage, with average density of $300 \mathrm{~cm}^{2}$.ave-1. Each facility can accommodate up to 100,000 Hy-Line W-36 laying hens. The photoperiod used in the facility was $16 \mathrm{~L}: 8 \mathrm{D}$ (natural + artificial light), the feed was supplied by automatic feeders and water by nipple drinkers, both ad libitum.

\section{Spatial behavior of the thermal conditions}

The spatial behavior of the thermal conditions was performed by analyzing the air temperature, air relative humidity and light intensity variables in the three-dimensional array of cage batteries. The data of air temperature and air relative humidity inside the facility were collected by DHT11 sensors, distributed in the vertical and longitudinal directions of thefacility.

Each collection point represented a set of coordinates $(\mathrm{x}, \mathrm{y}, \mathrm{z})$ being in the $\mathrm{x}$-axis the lines $(\mathrm{L} 1, \mathrm{~L} 2$, L3, L4, L5), in the y-axis the sections (S1, S2, S3, S4, $\mathrm{S} 5)$, and in the z-axis the tiers (N1, N2, N3) according to Figure 1. TiersN1, N2 and N3 correspond to the first, third and sixth cages of the batteries, respectively.

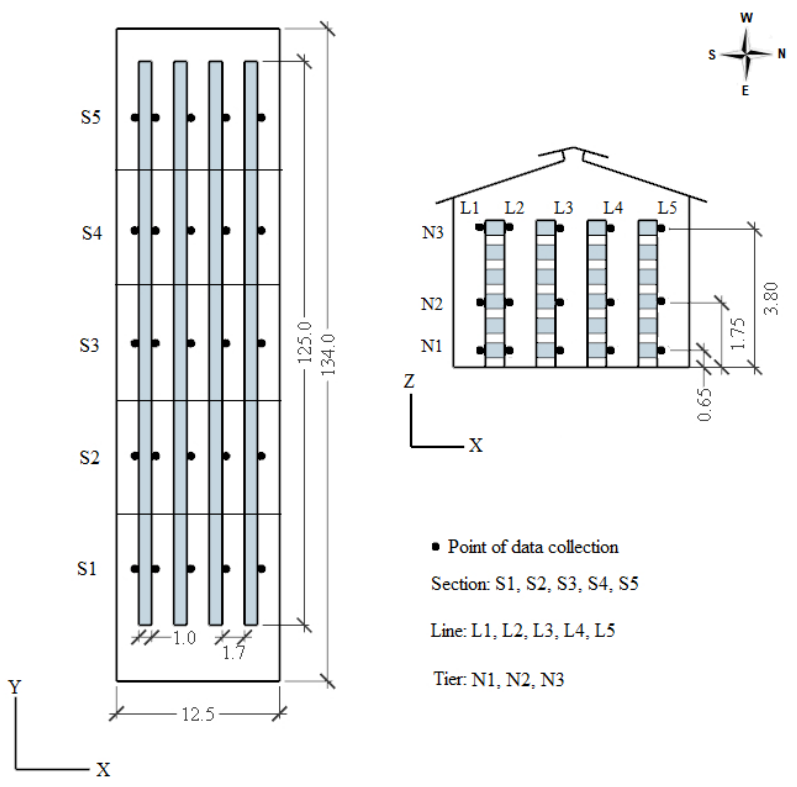

Figure 1: Spatial location of air temperature $\left({ }^{\circ} \mathrm{C}\right)$, air relative humidity of the air (\%) and light intensity (lux) data collection points. Dimensions in meters.

The data logger, based on the Arduino Mega 2560 board, were developed for process and record the data measured by the DHT11 sensors. Each data logger had a capacity of processing and store data from three DHT11. According to the manufacturer's specifications, for air temperature between $0{ }^{\circ} \mathrm{C}$ to $50{ }^{\circ} \mathrm{C}$ the sensor DHT11 accuracy is $\pm 2{ }^{\circ} \mathrm{C}$ and; for air relative humidity between $20 \%$ to $95 \%$ the accuracy is $\pm 5 \%$ (D-Robotics, 2010). To verify the spatial behavior of air temperature and air relative humidity in the facility, 75 sensors, and 25 data loggers were used. 


\section{Statistical analysis}

The experiment was conducted in July 2016 (winter) and January 2017 (summer). The air temperature and air relative humidity data inside the facility were recorded throughout 24 hours, every five minutes, during six days. The daily mean values of air temperature and air relative humidity obtained in summer and winter were divided in the dawn (00h00 to 05h00), morning (06h00 to $11 \mathrm{~h} 00)$, afternoon (12h00 to $17 \mathrm{~h} 00)$ and night (18h00 to $23 \mathrm{~h} 00$ ).

The experimental design was completely randomized in a factorial scheme. The collected data were submitted to analysis of variance and the means were compared by the Tukey test, at 5\% probability. The Software R, version 3.4.1, was used for the statistical analysis, Sigma Plot Software, version 12.0, for the elaboration of the graphs of air temperature and air relative humidity and the Software MINITAB, version 17.0 for the elaboration of the graphs of light intensity.

The factorial $2 \times 4$ analysis was initially performed with the first factor being the seasons of the year (winter and summer) and the second factor, the periods of the day (dawn, morning, afternoon, night). The spatial behavior of the thermal conditions of the facility was performed in the coldest period of winter and the warmst of summer. The factorial scheme adopted was $3 \times 5 \times 5$, with six replicates (days). The factors corresponded to tier (N1, $\mathrm{N} 2, \mathrm{~N} 3)$, section (S1, S2, S3, S4, S5) and line (L1, L2, L3, L4, L5).
The light intensity was measured at the same points where the DHT11 sensors were installed (Figure 1), using a lux meter (MINIPA modelo MLM-1011, São Paulo, Brazil). The lux meter has a measurement range of 0 to 100000 lux, with the accuracy of $4 \%$ from 0 to 10000 lux and above this range accuracy of 5\%.

The data were collected during summer and winter, three times a day: $9 \mathrm{~h} 00,12 \mathrm{~h} 00$ and $15 \mathrm{~h} 00$, for three days. The light intensity measurements were performed by only one lux meter, starting in the center towards the open sides of the facility. The reading time at each collection point was 30 seconds. The total time to perform the measurements was 60 minutes (displacement inside facility and measurement).

The spatial behavior of the light intensity of the facility was performed at the time of day that presented the highest light intensity, in winter and summer. The factorial scheme adopted was $3 \times 5 \times 5$, with three replicates (days). The factors corresponded to tier (N1, N2, N3), section (S1, S2, S3, S4, S5) and line (L1, L2, L3, L4, L5).

\section{RESULTS AND DISCUSSION}

There was a significant effect of the factors season (E) and period of the day (P) and of the interaction $\mathrm{E} \times \mathrm{P}$ in the air temperature values $(\mathrm{p}<$ $0.001)$ and air relative air humidity $(\mathrm{p}<0.001)$, inside the facility of laying hens. The effect of interaction between factors season $(\mathrm{E})$ and period of the day $(\mathrm{P})$ $(\mathrm{p}<0.001)$ on air temperature and air relative humidity value is represented in Table 1.

Table 1: Effect of the interaction between season (E) and period of day $(P)$ factors on air temperature $\left({ }^{\circ} \mathrm{C}\right)$ and air relative humidity (\%) values within facility laying hens.

\begin{tabular}{cccc}
\hline Variables & \multicolumn{3}{c}{ Interaction E x P } \\
\hline & & Winter & Summer \\
Air Temperature $\left({ }^{\circ} \mathrm{C}\right)$ & Dawn & $12.99(1.58) \mathrm{cB}$ & $20.25(0.63) \mathrm{bA}$ \\
& Morning & $17.58(1.22) \mathrm{bB}$ & $22.52(0.42) \mathrm{bA}$ \\
& Afternoon & $24.56(0.81) \mathrm{aB}$ & $27.27(0.43) \mathrm{aA}$ \\
& Night & $16.68(0.57) \mathrm{bB}$ & $22.32(0.98) \mathrm{bA}$ \\
\hline \multirow{2}{*}{ Air Relative Humidity (\%) } & & Winter & Summer \\
& Dawn & $67(5.52) \mathrm{aB}$ & $78(1.37) \mathrm{aA}$ \\
& Morning & $54(3.79) \mathrm{bB}$ & $69(2.08) \mathrm{bA}$ \\
& Afternoon & $33(3.45) \mathrm{cB}$ & $48(2.83) \mathrm{cA}$ \\
& Night & $56(1.89) \mathrm{bB}$ & $69(3.59) \mathrm{bA}$ \\
\hline
\end{tabular}

*Means followed by the same letter do not differ statistically among each other, uppercase in rows and lower case in the column, by Tukey test at $5 \%$ probability. 
The average air temperature was lower in the dawn of winter $\left(12.99^{\circ} \mathrm{C}\right)$ and higher in the summer afternoon $\left(27.27^{\circ} \mathrm{C}\right)$, as expected. The mean air relative humidity was lower in the winter afternoon (33\%) and higher in the dawn of summer (78\%). In this region, the winters are dry and the summers rainy, which may explain the great variation found between the values of air relative humidity inside the facility. The values of air temperature and air relative humidity obtained were lower than average values found by Pereira et al. (2017) in naturally ventilated facilities for laying hens in the region of Bastos-SP, both winter and summer. The difference in average values of air temperature and air relative humidity between the studies demonstrates the effect of regional climatic conditions on the thermal conditions inside the facility.

During the winter dawns, the laying hens were in natural cold stress conditions and during the summer afternoons, under natural heat stress conditions. Therefore, the spatial behavior of the air temperature and air relative humidity of the air in winter was performed with the values obtained in the dawn and in summer, with the values obtained in the afternoon.

The analysis of variance for the air temperature spatial behavior during winter indicated a significant effect $(\mathrm{p}<0.001)$ of tier $(\mathrm{N})$, section (S) and line (L) factors and their interactions. The effect of the $\mathrm{N} x \mathrm{~S} \times \mathrm{L}$ interaction on the air temperature values, based on the unfolding of the section and line factors within each tier is shown in Table 2.

In winter, there was a homogeneous behavior of the air temperature values between the sections (S1, S2, $\mathrm{S} 3, \mathrm{~S} 4, \mathrm{~S} 5$ ) and variable behavior between the lines (L1, L2, L3, L4, L5). The center line of the facility (L3) was where the highest air temperatures $\left(14.0{ }^{\circ} \mathrm{C}\right.$ to $\left.17.8^{\circ} \mathrm{C}\right)$ were found and in the lateral ones (L1 and L5) the lowest air temperatures $\left(13.8{ }^{\circ} \mathrm{C}\right.$ to $\left.8.5^{\circ} \mathrm{C}\right)$.

The homogeneity among the sections and the variation among the lines can be explained by the fact that the facility is located between two other facilities and the winter winds are predominantly calm. These conditions generate a region on the sides of the facility, with stable climatic characteristics keeping the sections with approximately equal air temperatures and the heat concentrated in the central lines of the facility. At the N1 and N2 tiers were found the highest values of average air temperature, as expected, due to the hot air, for being it denser, tending to rise and concentrate in the upper region of the facility near the cover.

Table 2: Comparison between the mean values of air temperature $\left({ }^{\circ} \mathrm{C}\right)$ in the winter period, for the interaction $\mathrm{N} \times \mathrm{S} \times \mathrm{L}$.

\begin{tabular}{|c|c|c|c|c|c|c|}
\hline \multicolumn{7}{|c|}{ Interaction $\mathrm{N} \times \mathrm{S} \times \mathrm{L}$} \\
\hline & & L1 & $\mathrm{L} 2$ & L3 & L4 & L5 \\
\hline \multirow{5}{*}{ N1 } & S1 & $12.7(1.2) \mathrm{aA}$ & $13.8(1.8) a A$ & $14.2(1.7) \mathrm{aA}$ & $10.8(1.7) \mathrm{aA}$ & $13.0(1.5) \mathrm{aA}$ \\
\hline & S2 & $10.4(2.0) a B$ & 13.6 (1.8) aAB & $16.2(1.4) \mathrm{aA}$ & 11.5 (1.3) aAB & $12.5(2.4) \mathrm{aAB}$ \\
\hline & S3 & $11.5(2.0) \mathrm{aA}$ & $12.9(1.5) \mathrm{aA}$ & 14.6 (1.4) aA & $10.4(1.8) a A$ & $9.6(1.9) \mathrm{aA}$ \\
\hline & S4 & $11.7(2.0) \mathrm{aA}$ & 11.0 (1.9) aA & 14.1 (1.3) aA & $9.3(2.0) \mathrm{aA}$ & $8.5(2.1) \mathrm{aA}$ \\
\hline & S5 & $11.4(2.0) \mathrm{aB}$ & $11.7(1.8) a B$ & 17.8 (1.6) aA & $9.3(2.0) \mathrm{aB}$ & $12.9(2.0) \mathrm{aB}$ \\
\hline \multirow{5}{*}{$\mathrm{N} 2$} & S1 & $10.1(2.0) a B$ & $13.3(2.1) \mathrm{aAB}$ & $16.0(2.0) \mathrm{aA}$ & 14.9 (1.3) $\mathrm{aAB}$ & $12.7(0.7) \mathrm{aAB}$ \\
\hline & S2 & $12.0(2.1) \mathrm{aA}$ & $14.2(1.9) \mathrm{aA}$ & 15.4 (1.7) aA & $14.1(1.4) \mathrm{aA}$ & $13.8(2.0) \mathrm{aA}$ \\
\hline & S3 & $11.5(2.0) \mathrm{aA}$ & $15.0(1.7) \mathrm{aA}$ & $15.4(1.5) \mathrm{aA}$ & $12.5(1.4) \mathrm{aA}$ & 10.2 (1.9) aA \\
\hline & S4 & $11.2(2.0) \mathrm{aAB}$ & $16.4(2.1) \mathrm{aA}$ & 14.5 (1.7) $\mathrm{aAB}$ & $11.4(2.1) \mathrm{aAB}$ & $9.6(2.0) \mathrm{aB}$ \\
\hline & S5 & $11.9(2.9) \mathrm{aAB}$ & 13.1 (1.9) $\mathrm{aAB}$ & 15.5 (1.7) aA & 13.5 (1.8) aAB & $9.1(2.0) a B$ \\
\hline \multirow{5}{*}{ N3 } & S1 & $10.1(2.1) \mathrm{aA}$ & $13.3(2.1) \mathrm{aA}$ & 14.0 (1.9) aA & $14.2(1.4) \mathrm{aA}$ & $12.8(0.4) \mathrm{aA}$ \\
\hline & S2 & $12.6(2.0) \mathrm{aA}$ & 13.0 (1.8) aA & 15.7 (1.8) aA & $14.3(1.4) \mathrm{aA}$ & $12.7(1.8) \mathrm{aA}$ \\
\hline & S3 & $11.8(2.0) \mathrm{aA}$ & 13.6 (1.7) aA & $15.4(1.8) \mathrm{aA}$ & 17.1 (1.6) aA & 12.0 (1.3) aA \\
\hline & S4 & $11.3(2.0) \mathrm{aA}$ & $12.3(2.0) \mathrm{aA}$ & 15.4 (1.3) aA & $14.0(2.1) \mathrm{aA}$ & $12.0(1.8) \mathrm{aA}$ \\
\hline & S5 & 13.5 (2.1) aA & $14.4(1.8) \mathrm{aA}$ & 17.5 (1.4) aA & $17.4(1.5) \mathrm{aA}$ & $11.4(1.8) \mathrm{aA}$ \\
\hline
\end{tabular}

${ }^{*}$ Means followed by the same letter do not differ statistically among each other, uppercase in rows and lower case in the column, by Tukey test at $5 \%$ probability. $\mathrm{N}_{1-3}-$ Tier; $\mathrm{S}_{1-5}-$ Section; and $\mathrm{L}_{1-5}-$ Line. 
By the analysis of variance it was verified that, in the summer, there was a significant effect $(p<0.001)$ of the tier $(\mathrm{N})$, section $(\mathrm{S})$ and line $(\mathrm{L})$ factors, and their interactions on the spatial behavior of air temperature. The effect of the $\mathrm{N} \times \mathrm{S} \times \mathrm{L}$ interaction on the air temperature values, based on the unfolding of the section and line factors within each tier, is shown in Table 3.

In summer, the spatial variability of air temperature values was more accentuated than in winter. There was a growing increase in the air temperature between tiers and greater heterogeneity among sections and lines. At the $\mathrm{N} 1$ tier, the air temperature ranged between $24.0^{\circ} \mathrm{C}$ and $29.8^{\circ} \mathrm{C}$, with the highest values found in sections $\mathrm{S} 1, \mathrm{~S} 2$ and $\mathrm{S} 3$, and in lines $\mathrm{L} 1$ and $\mathrm{L} 2$. At the $\mathrm{N} 2$ tier, the lowest air temperature values $\left(25.4{ }^{\circ} \mathrm{C}\right.$ and $\left.25.1^{\circ} \mathrm{C}\right)$ were observed in sections S4 and S5, and lines L4 and L5. At the N3 tier, the air temperature varied between $25.3{ }^{\circ} \mathrm{C}$ and $32.5{ }^{\circ} \mathrm{C}$, with the lowest air temperatures found in sections S4 and S5.

These results may be due to the direction of the wind, since it blew towards the Northwest direction, favoring the movement of the mass of air in the external region between the facilities, towards the section S5 for section S1. Therefore, the air temperature values obtained in sections S4 and S5 were lower than those obtained in sections S3,
S2 and S1. The spatial behavior of air temperature in winter and summer can be observed in Figure 2.

In winter, the heat concentrates in the central lines of the facility. At the $\mathrm{N} 2$ tier, the heat concentration was more homogeneous and covered a larger area when compared to the N1 and N3 tiers of heat (Figure 2). In the summer, the spatial behavior of the air temperature was variable between the tiers. At the N1 and N3 tiers, the heat concentrated at the beginning of the aviary, having a larger area of coverage at the N3 tier. At the N2 tier, the heat was irregularly distributed, with a cross-sectional range of heat concentration in the center of the facility (Figure 2).

Coelho et al. (2015) conducted a study on the variability of the thermal conditions in laying hens facility during the summer and found higher air temperatures and, therefore, a higher concentration of heat in the highest tier of cages. The authors report that this phenomenon is due to thermal radiation from the roof and to the accumulation of hot air coming from the lowers tiers of the facility.

The analysis of variance for the spatial behavior of the air relative humidity values in th facility in winter indicated a significant effect of level $(\mathrm{N})$, section $(\mathrm{S})$ and line $(\mathrm{L})$ factors $(\mathrm{p}<0.001)$, and of the interactions $\mathrm{N} \times \mathrm{S}$ $(p<0.01)$ and $\mathrm{N} \mathrm{x} \mathrm{L}(\mathrm{p}<0.001)$. The effect of tier factor and $\mathrm{N} x \mathrm{~S}$ and $\mathrm{N} x \mathrm{~L}$ interactions are shown in Table 4.

Table 3: Comparison between the mean values of air temperature $\left({ }^{\circ} \mathrm{C}\right)$ in the summer period, for the interaction $\mathrm{N} \times \mathrm{S} \times \mathrm{L}$.

\begin{tabular}{|c|c|c|c|c|c|c|}
\hline \multicolumn{7}{|c|}{ Interaction $\mathrm{N} \times \mathrm{S} \times \mathrm{L}$} \\
\hline & & L1 & $\mathrm{L} 2$ & L3 & L4 & L5 \\
\hline \multirow{5}{*}{ N1 } & S1 & $25.2(0.4) b B$ & $28.0(0.2) a b A B$ & $29.8(0.1) \mathrm{aA}$ & $25.8(0.4) a B$ & $25.7(0.7) a b B$ \\
\hline & S2 & $26.4(0.6) \mathrm{abAB}$ & $29.4(0.3) \mathrm{aA}$ & $25.1(0.3) \mathrm{bB}$ & 27.3 (1.2) aAB & 25.7 (2.1) abB \\
\hline & S3 & $29.2(0.6) \mathrm{aA}$ & $25.7(0.6) \mathrm{bB}$ & $25.8(0.5) b B$ & $25.7(0.4) a B$ & 27.3 (1.5) aB \\
\hline & S4 & $26.1(0.7) a b A$ & $26.2(0.4) \mathrm{bA}$ & $24.7(0.4) \mathrm{bA}$ & $24.7(0.4) \mathrm{aA}$ & $25.2(1.8) \mathrm{abA}$ \\
\hline & S5 & $25.0(0.6) \mathrm{bA}$ & 26.8 (1.0) abA & $25.6(0.4) \mathrm{bA}$ & $24.3(0.8) \mathrm{aA}$ & 24.0 (1.9) bA \\
\hline \multirow{5}{*}{ N2 } & S1 & $29.7(0.5) \mathrm{aA}$ & $29.1(0.2) a b A$ & $28.7(0.2) \mathrm{aA}$ & $27.4(0.4) a b A$ & $27.2(0.4) \mathrm{aA}$ \\
\hline & S2 & 28.7 (1.3) abA & $26.4(0.2) \mathrm{bcA}$ & $27.0(0.4) \mathrm{aA}$ & 25.6 (1.5) abA & 26.8 (1.6) aA \\
\hline & S3 & $27.8(0.8) a b A B$ & $30.1(0.4) \mathrm{aA}$ & $27.4(0.5) \mathrm{aAB}$ & $28.8(0.9) \mathrm{aAB}$ & 26.0 (1.9) aB \\
\hline & S4 & $30.0(0.7) a A$ & $25.5(0.2) \mathrm{cB}$ & $27.4(0.5) \mathrm{aAB}$ & $26.3(0.8) a b B$ & 27.9 (1.6) aAB \\
\hline & S5 & $25.9(0.7) \mathrm{bA}$ & $27.8(0.9)$ abcA & $26.5(0.9) \mathrm{aA}$ & $25.4(0.8) \mathrm{bA}$ & $25.1(1.5) \mathrm{aA}$ \\
\hline \multirow{5}{*}{ N3 } & S1 & $28.4(0.3) a B$ & $29.7(0.2) a b A B$ & $27.9(0.3) b B$ & $31.7(0.4) \mathrm{aA}$ & $26.4(0.6) \mathrm{aB}$ \\
\hline & S2 & $27.0(0.5) \mathrm{aBC}$ & $31.3(0.2) \mathrm{aA}$ & $32.5(0.3) \mathrm{aA}$ & $29.4(0.8) a b A B$ & $26.1(2.1) \mathrm{aC}$ \\
\hline & S3 & $26.7(0.5) \mathrm{aBC}$ & 29.6 (1.0) abAB & $28.4(0.5) \mathrm{bABC}$ & 30.4 (1.2) abA & $25.7(2.1) \mathrm{aC}$ \\
\hline & S4 & 26.7 (0.5) aA & $27.6(0.4) \mathrm{bA}$ & $28.0(0.5) \mathrm{bA}$ & 28.2 (0.7) bA & $25.8(2.0) \mathrm{aA}$ \\
\hline & S5 & $27.2(0.5) \mathrm{aAB}$ & 29.6 (1.3) abA & $28.2(0.6) \mathrm{bAB}$ & 28.8 (1.3) abA & 25.3 (2.7) aB \\
\hline
\end{tabular}

${ }^{*}$ Means followed by the same letter do not differ statistically among each other, uppercase in rows and lower case in the column, by Tukey test at $5 \%$ probability. $\mathrm{N}_{1-3}-$ Tier; $\mathrm{S}_{1-5}-$ Section; and $\mathrm{L}_{1-5}-$ Line. 

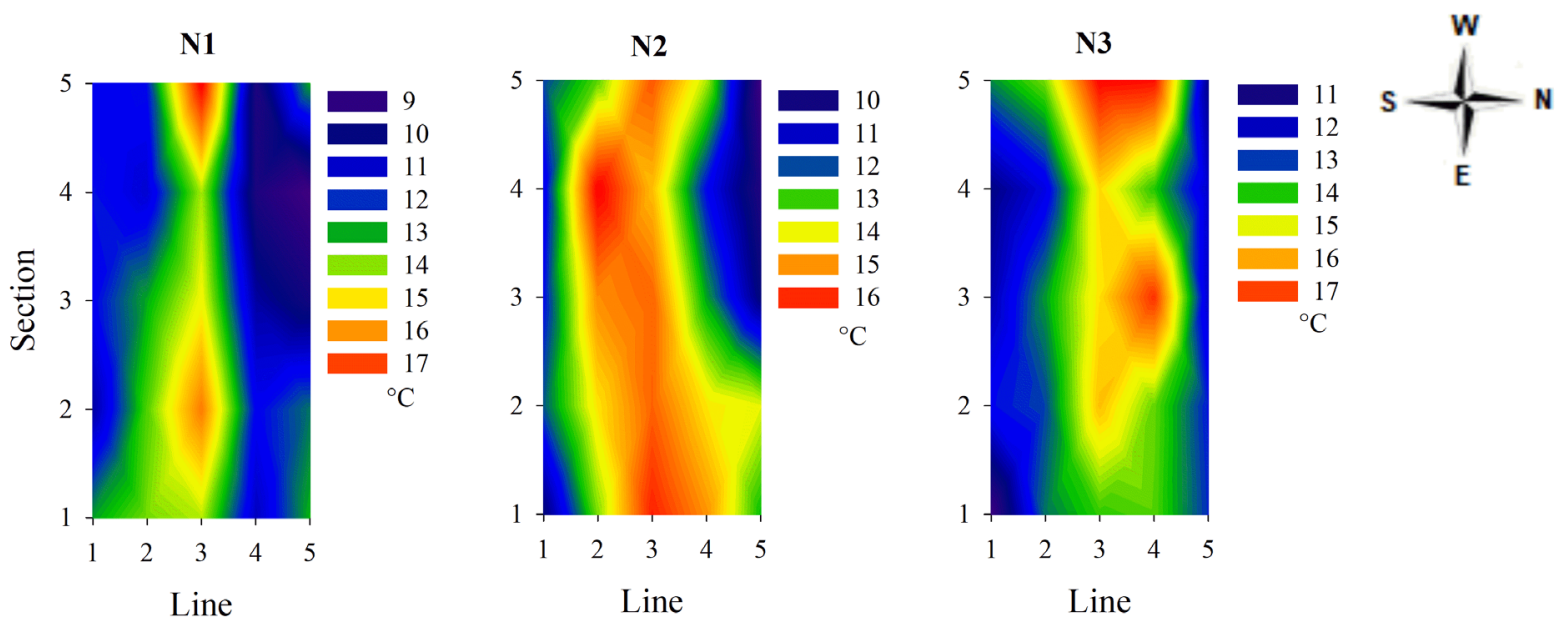

(a)
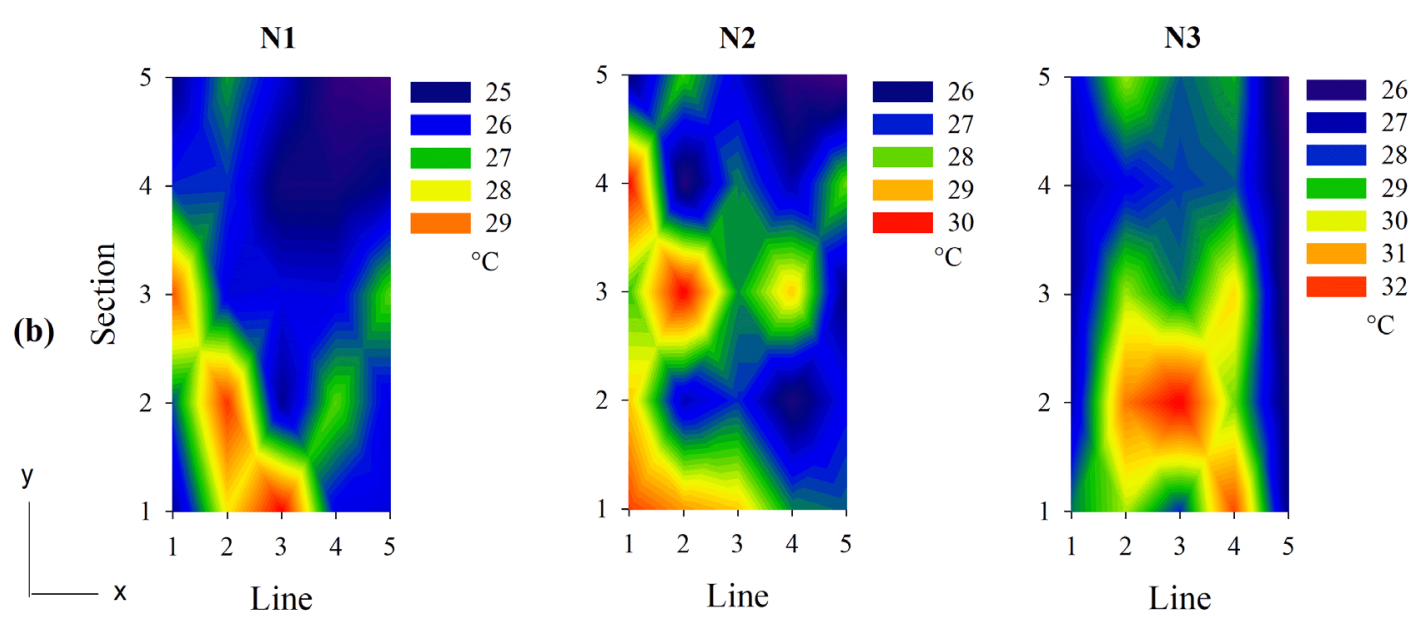

Figure 2: Spatial behavior of air temperature values, (a) in winter and (b) in summer.

Table 4: Comparison between mean values of air relative humidity of the air (\%) in the winter period, for the interactions $\mathrm{S} \times \mathrm{N}$ and $\mathrm{L} \times \mathrm{N}$.

\begin{tabular}{|c|c|c|c|c|c|}
\hline \multicolumn{6}{|c|}{ Interaction $\mathrm{N} \times \mathrm{L}$} \\
\hline & L1 & L2 & L3 & L4 & L5 \\
\hline N1 & 77 (9.3) aA & $67(6.7) a B$ & $55(5.2) \mathrm{aC}$ & $69(10.2) \mathrm{aB}$ & $80(9.5) a A$ \\
\hline N2 & $81(8.7)$ aA & 59 (6.3) bB & $50(2.8) \mathrm{aC}$ & $67(8.3) \mathrm{aD}$ & 78 (9.1) abA \\
\hline N3 & $76(8.0) \mathrm{aA}$ & 60 (6.4) abCD & 55 (5.9) aD & $63(8.2) a B C$ & $71(7.6) \mathrm{bAB}$ \\
\hline \multicolumn{6}{|c|}{ Interaction $\mathrm{N} \times \mathrm{S}$} \\
\hline & S1 & S2 & S3 & S4 & S5 \\
\hline N1 & $72(11.0) \mathrm{aAB}$ & $66(11.7) a B$ & 68 (12.2) aAB & 73 (12.4) aA & 68 (10.5) aAB \\
\hline N2 & 70 (14.9) abA & 63 (13.3) aA & 67 (13.0) aA & 67 (12.5) abA & 68 (13.7) aA \\
\hline N3 & 65 (11.2) bA & 63 (10.2) aA & 63 (9.3) aA & 64 (9.9) bA & 69 (8.6) aA \\
\hline
\end{tabular}

*Means followed by the same letter do not differ statistically among each other, uppercase in rows and lower case in the column, by Tukey test at $5 \%$ probability. $\mathrm{N}_{1-3}-$ Tier; $\mathrm{S}_{1-5}-$ Section; and $\mathrm{L}_{1-5}$ - Line. 
The highest mean value air relative humidity of air inside the facility was found at the N1 tier $(69 \%)$ and the lowest at the N3 tier (65\%). For all tiers, it was verified that in the lines L1 and L5 and in the sections S1 and S5 were found the highest values of air relative humidity and the line L3 and section S2, the lowest values. The highest mean air relative humidity value was observed in $81 \%$ of line L1 of tier N2 and the lowest value, in $50 \%$, in line L3 of tier N2. These results can be explained by the same reasons presented in the winter air temperature analysis. In other words, due to the location of the aviary and the predominance of calm winds in the South direction, they generate a region on the sides of the facility, with stable climatic characteristics keeping the air moist on the outer lines (L1 and L5) and dry air in the center of the facility (L3).

In the summer, the significant effect $(\mathrm{p}<0.001)$ of the tier $(\mathrm{N})$, section $(\mathrm{S})$ and line $(\mathrm{L})$ factors and their interactions were observed on the values of air relative humidity. The effect of the unfolding of section and line factors within each tier in the air relative humidity values is shown in Table 5.

In summer, air relative humidity of the air values varied between $34 \%$ and $62 \%$. These values were lower than those found by Coelho et al. (2015) in a naturally ventilated facility for laying hens, located in the same region of the present study and in the same month of summer (January). This difference between the results may be due to the region's rainfall indexes. According to the National Institute of Meteorology (INMET), in January of 2013, year of the research of Coelho et al. (2015), the rainfall index was 13.25 mm.day ${ }^{-1}$, which is higher than the value of $8.80 \mathrm{~mm}^{\text {day }}{ }^{-1}$, verified in January 2017, by the present research.

Even though being the summer a rainy season, the values of air relative humidity were low and presented a variability among the tiers, being the tier $\mathrm{N} 3$ the most homogeneous. This fact may be related to the spatial behavior of the air temperature inside the facility. The regions with the lowest values of air relative humidity presented higher air temperature values. The spatial behavior of air relative humidity in winter and summer can be observed in Figure 3.

In winter, dry air concentrated in a longitudinal range in the center of the facility, increasing the comprehensiveness area with increasing of the tiers. In summer, the spatial behavior of air relative humidity was variable between tiers. At the N1 tier, the moist air concentrated at the sides and at the end of the aviary, forming a central region with dry air. At the N2 tier, the dry air coverage area expanded as well as at the N3 tier.

Table 5: Comparison between the mean values of air relative humidity (\%) in the summer period, for the interaction $\mathrm{N} \times \mathrm{S} \times \mathrm{L}$.

\begin{tabular}{|c|c|c|c|c|c|c|}
\hline \multicolumn{7}{|c|}{ Interaction $\mathrm{S} \times \mathrm{L} \times \mathrm{N}$} \\
\hline & & L1 & L2 & L3 & L4 & L5 \\
\hline \multirow{5}{*}{ N1 } & S1 & 51 (5.6) abA & 45 (1.7) bA & 53 (2.4) abA & 53 (3.3) aA & $53(4.4) \mathrm{aA}$ \\
\hline & S2 & 44 (2.4) bA & $45(1.8) \mathrm{bA}$ & $47(2.1) \mathrm{bA}$ & $53(4.3)$ aA & $51(8.0)$ aA \\
\hline & S3 & $59(3.0) \mathrm{aA}$ & 54 (3.7) abA & $41(2.1) b B$ & 48 (1.6) aAB & $52(6.0) \mathrm{aAB}$ \\
\hline & S4 & 55 (3.4) abA & 55 (2.7) abA & $40(3.1) b B$ & $54(2.8) \mathrm{aA}$ & 56 (5.9) aA \\
\hline & S5 & $58(3.5) \mathrm{aA}$ & $60(5.1) \mathrm{aA}$ & $60(1.8) \mathrm{aA}$ & $61(6.3) \mathrm{aA}$ & $57(6.5) \mathrm{aA}$ \\
\hline \multirow{5}{*}{ N2 } & S1 & $57(3.2) \mathrm{aA}$ & $38(2.4) \mathrm{bcC}$ & $40(3.2) \mathrm{aBC}$ & 53 (3.5) abAB & $38(2.9) \mathrm{bC}$ \\
\hline & S2 & $46(2.4) \mathrm{abA}$ & 49 (2.6) abA & $45(2.2) \mathrm{aA}$ & $56(7.4) \mathrm{aA}$ & $53(7.9) \mathrm{aA}$ \\
\hline & S3 & $42(2.9) \mathrm{bAB}$ & $34(5.6) \mathrm{cB}$ & $45(1.7) \mathrm{aAB}$ & 41 (1.5) bAB & $52(6.7) \mathrm{aA}$ \\
\hline & S4 & $42(2.4) \mathrm{bA}$ & 39 (1.9) bcA & $42(1.5) \mathrm{aA}$ & 48 (1.9) abA & $51(6.2) a b A$ \\
\hline & S5 & 48 (3.7) abB & $62(2.7) \mathrm{aA}$ & $49(2.8) \mathrm{aB}$ & $56(9.2) \mathrm{aAB}$ & $49(6.4) \mathrm{abB}$ \\
\hline \multirow{5}{*}{ N3 } & S1 & $48(2.3) \mathrm{aA}$ & $45(2.0) \mathrm{aA}$ & $41(2.2) \mathrm{aA}$ & $45(2.4) \mathrm{aA}$ & 49 (3.7) aA \\
\hline & S2 & $39(2.1) \mathrm{aA}$ & $40(1.7) \mathrm{aA}$ & $44(2.2) \mathrm{aA}$ & $45(3.2) \mathrm{aA}$ & $48(5.3) \mathrm{aA}$ \\
\hline & S3 & $50(3.4) \mathrm{aAB}$ & $38(2.5) \mathrm{aB}$ & $42(1.4) \mathrm{aAB}$ & $47(2.0) \mathrm{aAB}$ & $54(7.2) \mathrm{aA}$ \\
\hline & S4 & $47(2.8) a A B$ & $45(1.6) \mathrm{aAB}$ & $40(2.4) \mathrm{aB}$ & $45(2.5) \mathrm{aAB}$ & $57(5.8) \mathrm{aA}$ \\
\hline & S5 & $39(2.3) \mathrm{aB}$ & 49 (3.3) aAB & $46(1.5) \mathrm{aAB}$ & $52(5.6) \mathrm{aAB}$ & $54(8.2) \mathrm{aA}$ \\
\hline
\end{tabular}

*Means followed by the same letter do not differ statistically among each other, uppercase in rows and lower case in the column, by Tukey test at $5 \%$ probability. $\mathrm{N}_{1-3}-$ Tier; $\mathrm{S}_{1-5}-$ Section and $\mathrm{L}_{1-5}-$ Line. 

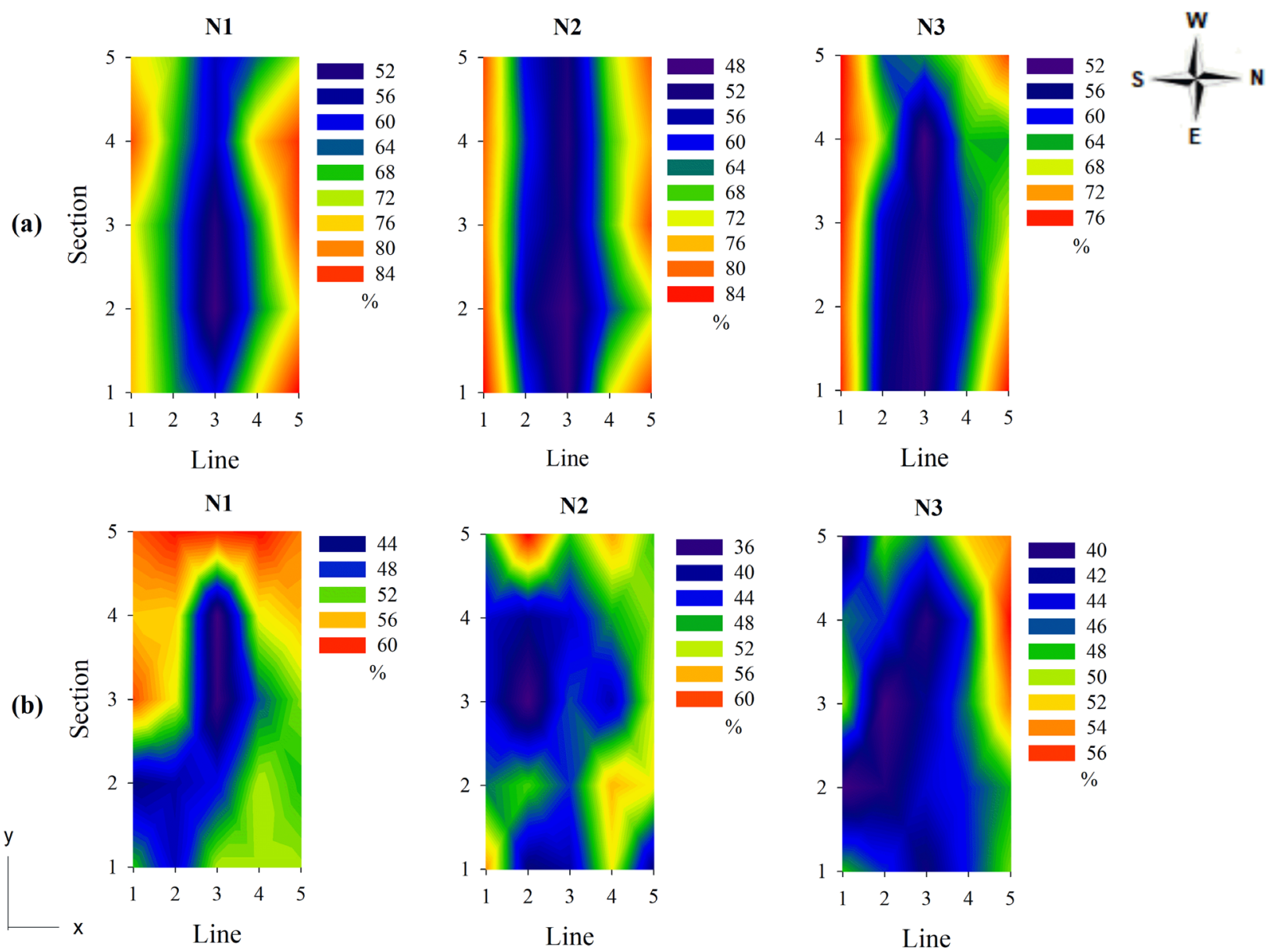

Figure 3: Spatial behavior of air relative humidity values, (a) in winter and (b) in summer.

The spatial thermal conditions behavior in the laying hen's facility, in the summer, showed a variation of air temperature between $24.0^{\circ} \mathrm{C}$ and $32.5^{\circ} \mathrm{C}$ and a variation of the air relative humidity, between $34 \%$ and $62 \%$. These results are in agreement with the results obtained by Biaggioni et al. (2008), Souza Junior et al. (2015) allowing for better utilization of nutrients. In this study, the relationship between the corn particle size, measured as the geometric mean diameter (GMD and Vitorasso and Pereira (2009) in studies conducted in the summer in naturally ventilated laying hens facilities.

In winter, the spatial behavior of the thermal conditions found a variation of air temperature, with values between $8.5^{\circ} \mathrm{C}$ and $17.8^{\circ} \mathrm{C}$ and a variation of air relative humidity from $50 \%$ to $81 \%$. Silva et al. (2017) verified in laying hens facility with naturally ventilated, values of air temperature and relative humidity close to those found in the present study.
However, it was observed that in winter the air temperature values inside the facility were below the thermal comfort threshold for laying hens. According to the Hy-Line Guide (2015), the ambient temperature that characterizes thermal comfort is between 18 and $24{ }^{\circ} \mathrm{C}$ and air relative humidity between 40 and $60 \%$, this range is, bellow than that predicted by Ferreira (2015), which is 24 at $26{ }^{\circ} \mathrm{C}$ and 60 at $70 \%$. In the summer, the N1 tier presented regions with air temperature values within the thermal comfort range, which was not verified at N2 and N3 tiers.

The values of light intensity found inside the facility were affected by the factor season of the year $(\mathrm{p}<$ $0.01)$ and time of day $(\mathrm{p}<0.001)$ and by the interaction between them $(p<0.05)$. The average light intensity in winter was higher than the average in summer. The time of day whit higher light intensity was around $12 \mathrm{~h} 00$. The effect of the interaction between season of the year (E) 
and time of day $(\mathrm{H})$ factors, on light intensity (lux) values inside the laying hen's facility is shown in Table 6.

In winter, due to the latitude of the site $\left(22^{\circ} 17\right.$ ' $45^{\prime}$ ' $\mathrm{S}$ and $44^{\circ} 56^{\prime} 05^{\prime}$ ' $\mathrm{W}$ ), there is a direct incidence of solar radiation in one side of the facility, which may be the cause of the high light intensity values measured. In the summer, there was no direct incidence of radiation and the values of light intensity on the sides of the facility were statistically the same ( $\mathrm{p}<0.001)$.

The values of light intensity in winter and summer had a significant effect $(\mathrm{p}<0.001)$ of the tier $(\mathrm{N})$ and line (L) factors, and of the interaction $\mathrm{N} x \mathrm{~L}$. The effect of the interaction in light intensity is given in Table 7.

It was verified that the values of light intensity were lower in the center (L2, L3 and L4) and higher in the side (L1, L5) of the facility, both in winter and summer. In the lower tiers of the cage batteries (N1 and N2) the intensity values measured were close to 30 lux, a value above that recommended by Cotta (2014) and Jácome, Rossi and
Borille, (2014). The spatial behavior of the light intensity at the three tiers $(\mathrm{N} 1, \mathrm{~N} 2, \mathrm{~N} 3)$ in winter and summer is plotted in Figure 4.

The values of light intensity measured in the laying hen's facility were above the values found by Vitorasso and Pereira (2009) in naturally ventilated facility. Yıldız et al. (2006) found that high variability in light intensity in the open facility may be responsible for the poor egg quality and performance. The authors suggested a light intensity supply with values between 35 and 55 lux in open facility, values these, found in the center of the aviary of the present study.

Ma et al. (2016) found that light intensity may influence feed intake. Feed intake decreased with increasing light intensity. The values evaluated were $1,5,15,30$ and 100 lux. Therefore, a variation of feed intake can be expected in the studied facility, since there is a spatial variability of the values of light intensity.

Table 6: Effect of the interaction between season of the year $(\mathrm{E})$ and time of day $(\mathrm{H})$ factors, on luminous intensity (lux) values inside the laying hen's facility.

\begin{tabular}{|c|c|c|c|}
\hline Variable & \multicolumn{3}{|c|}{ Interactions E x H } \\
\hline \multirow{4}{*}{$\begin{array}{l}\text { Light Intensity } \\
\quad \text { (Iux) }\end{array}$} & & Winter & Summer \\
\hline & 09:00 & 7724 (188.5) bA & 4331 (407.7) aB \\
\hline & $12: 00$ & 10397 (1916.9) aA & 4199 (874.4) aB \\
\hline & $15: 00$ & 7742 (294.6) bA & 2993 (882.5) aB \\
\hline
\end{tabular}

${ }^{*}$ Means followed by the same letter do not differ statistically among each other, uppercase in rows and lower case in the column, by Tukey test at $5 \%$ probability.

Table 7: Comparison between the mean values of light intensity (lux) in summer and winter for the interaction $\mathrm{N} \times \mathrm{L}$.

\begin{tabular}{cccccc}
\hline \multicolumn{5}{c}{ Interaction $\mathrm{N} \times \mathrm{L}$} \\
\hline Winter & $\mathrm{L} 1$ & $\mathrm{~L} 2$ & $\mathrm{~L} 3$ & $\mathrm{~L} 4$ & $\mathrm{~L} 5$ \\
$\mathrm{~N} 1$ & $65933(6228) \mathrm{aA}$ & $23(4) \mathrm{aB}$ & $14(2) \mathrm{aB}$ & $33(7) \mathrm{aB}$ & $3467(284) \mathrm{aB}$ \\
$\mathrm{N} 2$ & $60653(6856) \mathrm{bA}$ & $50(8) \mathrm{aBC}$ & $20(3) \mathrm{aC}$ & $32(5) \mathrm{aC}$ & $4671(495) \mathrm{aB}$ \\
$\mathrm{N} 3$ & $12313(1625) \mathrm{CA}$ & $522(45) \mathrm{aC}$ & $948(70) \mathrm{aC}$ & $1520(132) \mathrm{aBC}$ & $5759(798) \mathrm{aB}$ \\
\hline
\end{tabular}

Summer

L1

$\begin{array}{ll}\text { N1 } & 12200(3328) a A \\ \text { N2 } & 11053(2546) a b A\end{array}$

L2

$65(38) \mathrm{aB}$
$102(52) \mathrm{aB}$

$212(45) \mathrm{aB}$

L3
L4

$$
\begin{array}{r}
44(32) a B \\
63(5) a B
\end{array}
$$$$
1038(180) \mathrm{aB}
$$

L5

10420 (2912) aA

10647 (2662) aA

8473 (1683) aA

${ }^{*}$ Means followed by the same letter do not differ statistically among each other, uppercase in rows and lower case in the column, by Tukey test at $5 \%$ probability. $\mathrm{N}_{1-3}-$ Tier; $\mathrm{S}_{1-5}-$ Section and $\mathrm{L}_{1-5}$ - Line. 
(a)

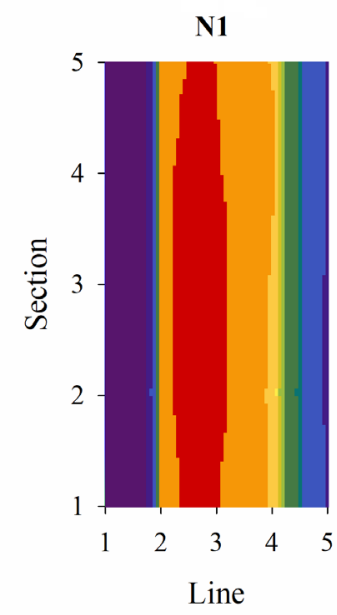

(b)

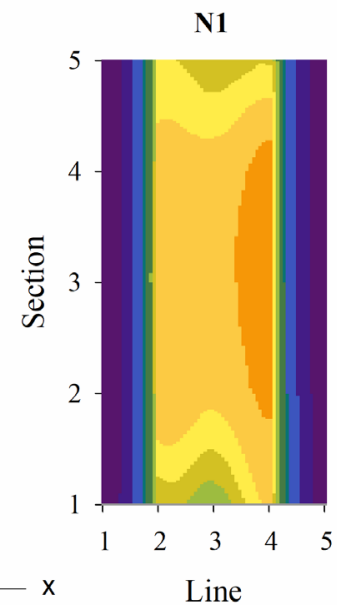

N2

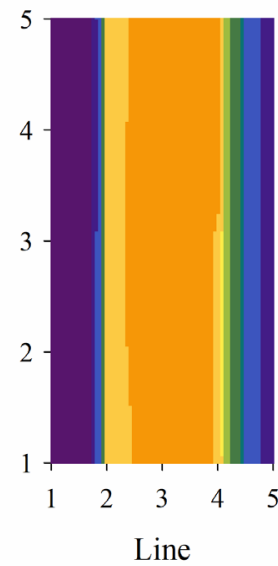

N2

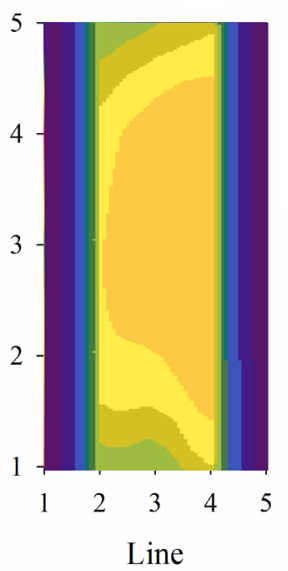

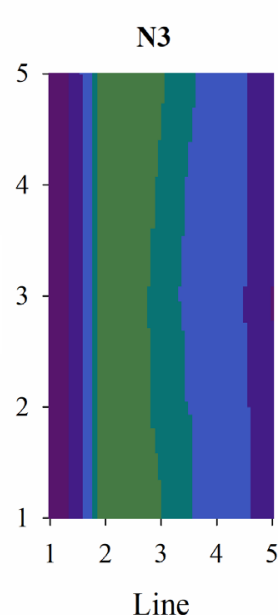

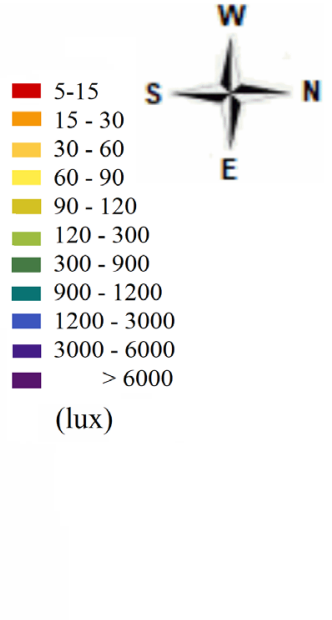

N3

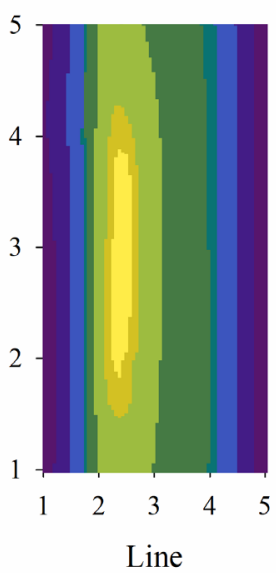

Figure 4: Spatial behavior of light intensity values, (a) in winter and (b) in summer.

The spatial behavior of the thermal conditions was used by Zhao et al. (2015) in a comparative study between a housing with vertical cage system, one with enriched cage and one without cages. The study was part of a multidisciplinary and multi-institutional project carried out by educational institutions, government agencies and private companies in the United States to obtain information on the thermal conditions and air quality of these types of production systems. This project emphasizes the importance of the monitoring and spatial characterization of the breeding environment in the animal production.

\section{CONCLUSIONS}

The survey of the spatial behavior of the environmental conditions of laying hens facility is an effective tool to verify the magnitude of air temperature, air relative humidity and light intensity in a detailed way. Through the spatial behavior, it is possible to detect islands of heat and humidity and observe the dynamics of these variables in the facility. The knowledge of the spatial behavior of the environment provides information that can be used to make decisions about the correct conditioning system to be implanted, its management and efficiency. In a tropical country, with a great climatic variability between regions, it is crucial to have information about the production environment, for it influences, directly and indirectly, the productivity and quality of eggs.

\section{ACKNOWLEDGEMENTS}

The authors thank the National Council for Scientific and Technological Development (CNPq), the 
Coordination for the Improvement of Higher Education Personnel (CAPES), the Foundation for Research Support of the State of Minas Gerais (FAPEMIG), the Department of Agricultural Engineering of the Federal University of Viçosa (DEA-UFV) and the Center for Research in Environment and Agroindustry Systems Engineering (AMBIAGRO) for the granting of a scholarship and financial aid, and also, the company where the experiment was carried out, for the partnership and assistance on the study.

\section{REFERENCES}

ALBINO, L. F. T. et al. Galinhas poedeiras: Criação e alimentação. Viçosa: Aprenda Fácil, 2014. 376p.

BALAMURUGAN, B. et al. Effect of global warming on livestock production and reproduction: An overview. Journal of Veterinary Science and Technology, 6(3):12-18, 2017.

BIAGGIONI, M. A. M. et al. Desempenho térmico de aviário de postura acondicionado naturalmente Thermal. Ciências Agrárias, 29(4):961-972, 2008.

COELHO, D. J. R. et al. Mapeamento do ambiente térmico de aviários de postura abertos em sistema vertical de criação. Revista Brasileira de Engenharia Agrícola e Ambiental, 19(10):996-1004, 2015.

COTTA, J. T. de B. Galinha: Produção de ovos.Viçosa: Aprenda Fácil, 2014. 250p.

FERREIRA, R. A. Maior produção com melhor ambiente para aves, suínos e bovinos. Viçosa: Aprenda Fácil, 2015. 526p.
JÁCOME, I. M. T. D.; ROSSI, L. A.; BORILLE, R. Influence of artificial lighting on the performance and egg quality of Commercial layers: A review. Revista Brasileira Ciência Avícola, 16(4):337-344, 2014.

MA, H. et al. Assessment of lighting needs by W-36 laying hens via preference test. Animal, 10(4):671-680, 2016.

NUNES, K. C. et al. Led como fonte de luz na avicultura de postura. Enciclopédia Biosfera, 9(17):1765-1782, 2013.

PEREIRA, D. F. et al. Technical feasibility of the acclimatization system in aviary of posture: A case study. Engenharia Agrícola, 37(5):855-866, 2017.

SILVA, L. F. et al. Índices bioclimáticos em aviários de postura em diferentes fases produtivas. Caderno de Ciências Agrárias, 9(3):31-37, 2017.

SOUZA JUNIOR, J. B. F. et al. The relationship between corn particle size and thermoregulation of laying hens in an equatorial semi-arid environment. International Journal of Biometeorology, 59(1):121-125, 2015.

VITORASSO, G.; PEREIRA, D. F. Análise comparativa do ambiente de aviários de postura com diferentes sistemas de acondicionamento. Revista Brasileira de Engenharia Agrícola e Ambiental, 13(6):788-794, 2009.

YILDIZ, A. et al. Effects of cage location and tier level with respect to light intensity in semiconfined housing on egg production and quality during the late laying period. Journal of applied poultry research, 15(3):355-361, 2006.

ZHAO, Y. et al. Environmental assessment of three egg production systems - Part I : Monitoring system and indoor air quality. Poultry Science, 94(3):518-533, 2015. 